\title{
K-ras2 activation and genome instability increase proliferation and size of FAP adenomas
}

\author{
Anna Rapallo a , Andrea Sciutto ${ }^{\text {a }}$, Elio Geido ${ }^{\text {a }}$, \\ Roberto Orecchia ${ }^{\text {a }}$, Edmondo Infusini ${ }^{\text {a }}$, \\ Natalija Pujic ${ }^{\text {a }, ~ E m a n u e l e ~ S . G . ~ d ' A m o r e ~}{ }^{b}$, \\ Roberto Monaco ${ }^{c}$, Mauro Risio ${ }^{d}$, \\ Francesco P. Rossini ${ }^{\mathrm{e}}$ and Walter Giaretti ${ }^{\mathrm{a}, *}$ \\ ${ }^{a}$ Laboratory of Biophysics and Cytometry, National \\ Cancer Institute (IST), Genoa, Italy \\ ${ }^{\mathrm{b}}$ Pathology Service, University of Padua, Italy \\ c Pathology Service, Cardarelli Hospital, Naple, Italy \\ ${ }^{\mathrm{d}}$ Pathology Service, National Institute for Cancer \\ Research and Treatment, Candiolo, Turin, Italy \\ e Service of Gastroenterology, ASL1, S. Giovanni \\ Vecchio Hospital, Turin, Italy
}

Received 10 August 1999

Accepted 23 September 1999

The possible role of K-ras2 mutations and aneuploidy toward increase of proliferation and adenoma size in Familial Adenomatous Polyposis (FAP) adenomas is not known. The present study addresses these issues by investigating 147 colorectal adenomas obtained from four FAP patients. The majority of adenomas had size lower than or equal to $10 \mathrm{~mm}(86 \%)$, low grade dysplasia (63\%), and were preferentially located in the right colon $(60 \%)$. Normal mucosa samples were obtained from 19 healthy donors. Three synchronous adenocarcinomas were also investigated. K-ras2 mutation spectrum was analysed by PCR and Sequence Specific Oligonucleotide (SSO) hybridization, while flow cytometry (FCM) was used for evaluating degree of DNA ploidy and S-phase fraction. Overall, incidences of K-ras2 mutations, DNA aneuploidy and high S-phase values $(>7.2 \%)$ were $6.6 \%, 5.4 \%$ and $10.5 \%$, respectively. In particular, among the adenomas with size lower than $5 \mathrm{~mm}$, K-ras $2 \mathrm{mu}-$ tation and DNA aneuploidy frequencies were only slightly above $1 \%$. Statistically significant correlations were found

\footnotetext{
*Correspondence address: Dr Walter Giaretti, Laboratory of Biophysics-Cytometry, National Cancer Institute (I.S.T.), Largo Rosanna Benzi, n. 10, 16132 Genova, Italy. Tel.: +39 105600969 ; Fax: +39 10 5600711; E-mail: giaretti@hp380.ist.unige.it.
}

between K-ras2 and size, DNA ploidy and size and K-ras2 and S-phase $(p<0.001)$. In particular, among the wild type K-ras2 adenomas, high S-phase values were detected in $8 \%$ of the cases versus $57 \%$ among the K-ras 2 mutated adenomas $(p=0.0005)$. The present series of FAP adenomas indicates that K-ras2 activation and gross genomic changes play a role toward a proliferative gain and tumour growth in size. Keywords: FAP, colorectal adenomas, ras gene, aneuploidy, proliferation

\section{Introduction}

Familial Adenomatous Polyposis (FAP) syndrome, characterized by hundreds of adenomatous polyps of different size and degree of dysplasia, is a highly penetrant autosomal dominant disorder associated with the germ line mutation of the APC gene [17,22,24,33]. If colectomy is not performed, FAP patients have a high probability of developing one or more colorectal cancers. Colorectal cancer development in FAP and sporadic patients is considered to be due to the accumulation of several genetic events including inactivation of the APC gene, mutations of K-ras2, p53 and DCC, and $\mathrm{LOH}$ of several chromosomes as recently indicated using Comparative Genomic Hybridization [7,9, $20,27,37,42]$. K-ras 2 mutations in FAP colorectal tumors were suggested to play a secondary role, since the mutation incidence in the small FAP adenomas is low (lower than 10\%) while the second APC allele is already mutated in about $50 \%$ of the cases [2,20,25,27]. $\mathrm{K}$-ras 2 mutation incidence in colorectal tumours, more frequent in the polyp forming cancer, is up to about $50 \%$ in both sporadic adenomas and adenocarcinomas $[9,42]$, while in the non-neoplastic aberrant crypt foci considered to be early precursors of adenomas was detected up to $85 \%[35,36,41,44]$.

Recently, new functions of the Ras proteins were suggested with the discovery of a plethora of new effector pathways and different cellular mechanisms in- 
cluding phosphorylation of transcription factors in the MAP kinase cascade [6] and association with proliferation $[1,4,40]$, apoptosis $[8,23,43]$, cytoskeleton organization $[19,34]$, chromosome stability and mitotic integrity $[18,32]$. We have previously shown by DNA flow cytometry (FCM) that human sporadic colorectal adenomas were characterized by an incidence of DNA aneuploidy of about $30 \%$ mainly distributed in the near-diploid region $[11,14,16]$. Aneuploidization mechanisms in sporadic colorectal adenomas were also suggested to be dependent from K-ras2 oncogene mutational activation while specific mutations $(\mathrm{G} \rightarrow \mathrm{A}$ transitions in codon 12) were associated to inhibition of proliferation [12,15].

Since literature data on the relationships among Kras 2 mutations, aneuploidy, proliferation, and growth in size in human colorectal adenomas from patients with the FAP syndrome are very scanty, we have decided to address these issues in the present study. In particular for a single patient, who underwent total colectomy, we mapped and analyzed a relatively large number of small adenomas ( $66 \%$ of a total of 123 adenomas had size lower than $5 \mathrm{~mm}$ ).

\section{Material and methods}

\subsection{Study population}

The study was performed on 147 polyps (size range between 2 and $35 \mathrm{~mm}$; mean $=6.3 \pm 5.3 \mathrm{~mm}$ ) with a histological diagnosis of adenomas and 3 adenocarcinomas from 4 FAP patients ( 3 females, 1 male). 87 adenomas were located in the right colon (including caecum, ascending colon, hepatic flexure and transverse colon), and 60 in the left colon (including splenic flexure, descending and sigmoid colon, and rectum). Patients were $19-53$ years old (mean $=31$ years). Control samples were taken from the normal FAP mucosa (12 samples) and from 19 healthy donors.

\subsection{Histological analysis and topographic selection}

Polyps were divided into two specular parts by a central mid-saggital section. One specimen was fixed in $10 \%$ buffered formalin for $24 \mathrm{~h}$, handled according to customary and histopathological diagnosis protocols and embedded in paraffin. The other specimen was used to provide fresh-frozen multiple samples for the FCM and PCR amplification. Histological diagnosis and grading were according to the World Health Organization criteria [21]. Dysplasia was divided in low grade, including mild and moderate, and high grade, corresponding to severe dyplasia. We obtained 93 low grade and 54 high grade dysplastic adenomas. Regarding dimensions, we had 84 polyps smaller than $5 \mathrm{~mm}$, 43 polyps ranging from 5 to $10 \mathrm{~mm}$, and 20 polyps larger than $10 \mathrm{~mm}$ in diameter (Table 1).

Table 1

Age, sex, site, size, and dysplasia in 147 adenomas from 4 FAP patients

\begin{tabular}{|c|c|c|c|c|c|c|}
\hline \multirow{2}{*}{$\begin{array}{l}\text { Patients } \\
\left.\text { (sex }{ }^{\mathrm{a}} / \mathrm{age}\right)\end{array}$} & \multirow[t]{2}{*}{ Site $^{b}$} & \multicolumn{3}{|c|}{ Size $(\mathrm{mm})$} & \multicolumn{2}{|c|}{ Dysplasia $^{\mathrm{c}}$} \\
\hline & & $<5$ & $5 \leqslant S \leqslant 10$ & $>10$ & $\mathrm{LG}$ & $\mathrm{HG}$ \\
\hline \multirow[t]{2}{*}{ TO1(F/19) } & $\mathrm{R}$ & 55 & 10 & - & 38 & 27 \\
\hline & $\mathrm{L}$ & 26 & 23 & 9 & 33 & 25 \\
\hline \multirow[t]{2}{*}{ PD1(M/53) } & $\mathrm{R}$ & 1 & 9 & 5 & 15 & - \\
\hline & $\mathrm{L}$ & - & - & - & - & - \\
\hline \multirow[t]{2}{*}{ NA1(F/23) } & $\mathrm{R}$ & 1 & 1 & 3 & 5 & - \\
\hline & $\mathrm{L}$ & 1 & - & - & 1 & - \\
\hline \multirow[t]{2}{*}{ NA2(F/29) } & $\mathrm{R}$ & - & - & 2 & 1 & 1 \\
\hline & $\mathrm{L}$ & - & - & 1 & - & 1 \\
\hline \multirow[t]{3}{*}{ Total } & $\mathrm{R}$ & 57 & 20 & 10 & 59 & 28 \\
\hline & $\mathrm{L}$ & 27 & 23 & 10 & 34 & 26 \\
\hline & $\mathrm{R}+\mathrm{L}$ & 84 & 43 & 20 & 93 & 54 \\
\hline Frequency & & $57 \%$ & $29 \%$ & $14 \%$ & $63 \%$ & $37 \%$ \\
\hline
\end{tabular}

${ }^{\mathrm{a}} \mathrm{M}=$ male; $\mathrm{F}=$ female.

${ }^{\mathrm{b}} \mathrm{R}$, right colon includes caecum, ascending colon, hepatic flexure, and transverse colon; L, left colon includes splenic flexure, descending colon, sigmoid colon, and rectum.

${ }^{\mathrm{c}} \mathrm{LG}=$ low grade dysplasia; $\mathrm{HG}=$ high grade dysplasia. 


\subsection{DNA flow cytometry}

Tissue fragments were minced with scalpels for 1 to 2 minutes directly in the staining solution composed of $10 \mathrm{mM}$ phosphate-buffer in isotonic saline, $1 \mathrm{mM}$ $\mathrm{CaCl}_{2}, 0.5 \mathrm{mM} \mathrm{MgSO} 4,0.6 \%$ Nonidet P40 (v/v), $0.2 \%$ bovine serum albumin (w/v), and $10 \mathrm{mg} / \mathrm{l}$ of DAPI (Sigma Chemical Co., St. Louis, MO). Nuclei suspensions were measured by flow cytometry as previously detailed $[15,16]$. $\mathrm{G}_{0}-\mathrm{G}_{1}$ DNA content in adenomas was considered aneuploid in presence of an extra $G_{0}-G_{1}$ peak. Trout erythrocytes and individualspecific normal mucosa were also used as reference DNA standards. The degree of DNA aneuploidy (DI) was calculated as ratio of mean channel number of epithelial aneuploid $\mathrm{G}_{0}-\mathrm{G}_{1}$ peak to mean channel number of peak corresponding to normal mucosa and/or tissue infiltrating $\mathrm{G}_{0}-\mathrm{G}_{1}$ lymphocytes. The mean coefficient of variation $(\mathrm{CV})$ was $3.3 \pm 0.7 \%$. The S-phase fraction was evaluated on the whole samples using dedicated software (Phoenix Flow Systems). Aliquots of approximately 20000 nuclei obtained from the same suspension were collected to perform K-ras2 mutation analysis.

\subsection{K-ras2 analysis}

Extracted DNA from peripheral blood lymphocytes from healthy donors were used as wild type K-ras2 codon 12 GGT-gly and codon 13 GGC-gly controls. Additionally, 6 cell line extracted DNAs were used as controls for known K-ras2 mutations as previously described [12]. FAP samples were collected in aliquots of 20000 nuclei, stored at $-80^{\circ} \mathrm{C}$, and amplified by polymerase chain reaction, as previously detailed [12]. Oligonucleotide 20-mer panel (TIB MOLBIOL, Advanced Biotechnology Center, Genoa, Italy) for sequence specific oligonucleotide hybridization included K-ras 2 codon 12 and 13 wild type sequences, all possible mutations of codon 12, and the AGC and GAC mutations of codon 13 . The probes were $5^{\prime}$-end labeled by phosphorylation with $\left[\gamma-{ }^{32} \mathrm{P}\right] \mathrm{ATP}$, according to the standard method [39]. Dot blot and hybridization were done as usual [15].

\subsection{Statistical analysis}

Contingency tables were used to evaluate the correlation among K-ras2 status, DNA index, S-phase fraction values and the other adenoma parameters (site, size, dysplasia). Statistical significance was evaluated by means of the Chi-square test, with the Yates correction when appropriate, and was set in advance at $p=0.01[10]$.

\section{Results}

Figure 1 shows two examples of the flow cytometric analysis of DNA content of FAP adenoma samples: in Fig. 1A only one diploid peak is visible, in B an extra DNA-aneuploid peak in the near-triploid region was detected.

Table 1 summarizes the distribution of site, size and dysplasia of 147 adenomas belonging to 4 FAP patients. The first patient was investigated by analyzing a total of 123 adenomas whose mean size and SD were $5 \pm 3 \mathrm{~mm}$. Overall, the size of $57 \%$ of the adenomas was smaller than $5 \mathrm{~mm}$, ranged between 5 and $10 \mathrm{~mm}$ in $29 \%$, and was greater than $10 \mathrm{~mm}$ in $14 \%$ of the present series only. About $60 \%$ of the polyps were located in the right colon and $40 \%$ in the left. Regarding the grade dysplasia, $63 \%$ of the adenomas were low grade and $37 \%$ were high grade.
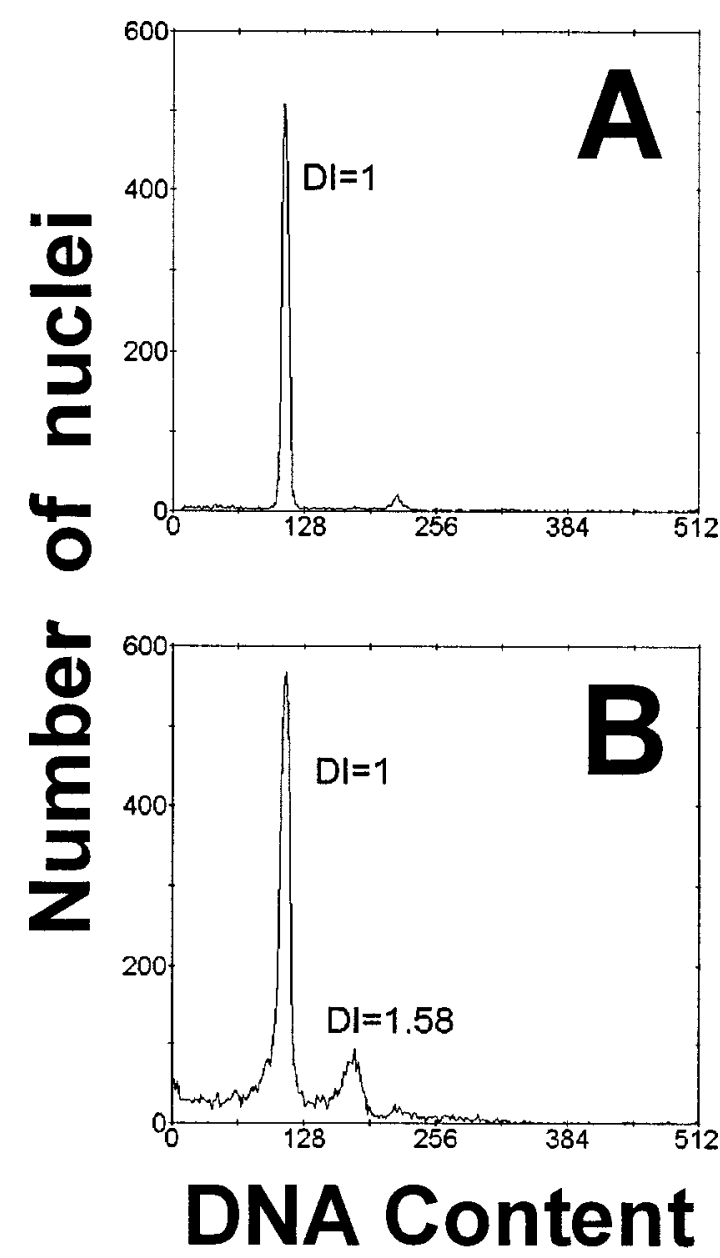

Fig. 1. Examples of DNA content analysis of two FAP adenoma samples by flow cytometry (see the text Result section). 
Table 2

K-ras2 mutations, DNA aneuploidy, and high S-phase among 147 colorectal adenomas and 3 adenocarcinomas in 4 FAP patients

\begin{tabular}{|c|c|c|c|c|c|}
\hline Patients & $\begin{array}{c}\text { N. of tumours } \\
\text { analyzed }\end{array}$ & $\begin{array}{c}\text { Mean size } \\
(\mathrm{mm} \pm \mathrm{SD})\end{array}$ & $\begin{array}{c}\text { K-ras2 } \\
\text { mutations }\end{array}$ & $\begin{array}{c}\text { DNA } \\
\text { aneuploidy }\end{array}$ & High-S $^{\mathrm{a}}$ \\
\hline \multicolumn{6}{|l|}{ Adenomas } \\
\hline TO1 & 123 & $5 \pm 3$ & $2 / 113(1.8 \%)$ & $4 / 123(3.2 \%)$ & $9 / 121(7.4 \%)$ \\
\hline PD1 & 15 & $9.8 \pm 4$ & $5 / 15(33 \%)$ & $0 / 15(0 \%)$ & $4 / 15(26.7 \%)$ \\
\hline NA1 & 6 & $18.8 \pm 14.7$ & $0 / 6(0 \%)$ & $2 / 6(33 \%)$ & $2 / 6(33 \%)$ \\
\hline NA2 & 3 & $17 \pm 2.9$ & $2 / 3(67 \%)$ & $2 / 3(67 \%)$ & $0 / 1(0 \%)$ \\
\hline Total tumours & 147 & $6.3 \pm 5.3$ & $9 / 137(6.6 \%)$ & $8 / 147(5.4 \%)$ & $15 / 143(10.5 \%)$ \\
\hline \multicolumn{6}{|c|}{ Synchronous adenocarcinomas } \\
\hline PD1 & 2 & & $0 / 2$ & $0 / 2$ & $0 / 2$ \\
\hline NA2 & 1 & & $0 / 1$ & $1 / 1$ & $1 / 1$ \\
\hline
\end{tabular}

${ }^{a}$ High S-phase threshold value was $7.2 \%$ as determined on the basis of the mean S-phase value $(5.1 \pm$ $0.7 \%$ ) added of 3SD determined in multiple samples of normal mucosa obtained from 19 healthy donors. S-phase was rejected in 4 cases $(2.7 \%)$ due to high CV and background values.

Table 3

Adenoma site/size, dysplasia, specific K-ras2 mutations, DNA Index, and S-phase fraction values of $9 \mathrm{~K}$-ras 2 mutated FAP colorectal adenomas

\begin{tabular}{cccccc}
\hline Patient & $\begin{array}{c}\text { Adenoma } \\
\text { site/size }^{\mathrm{a}}\end{array}$ & Dysplasia $^{\mathrm{b}}$ & $\begin{array}{c}\text { K-ras }^{\mathrm{c}} \\
\text { mutations }^{\text {R }}\end{array}$ & $\begin{array}{c}\text { DNA Index } \\
(\mathrm{CV})\end{array}$ & $\begin{array}{c}\text { S-phase } \\
\text { fraction }(\%)\end{array}$ \\
\hline R/10 & LG & GAC & $1.0(3.0 \%)$ & 3.2 \\
PD1 & R/15 & LG & TGT & $1.0(2.4 \%)$ & 5.2 \\
& R/10 & LG & TGT & $1.0(2.2 \%)$ & 7.3 \\
& R/17.5 & LG & TGT & $1.0(2.7 \%)$ & 7.6 \\
& R/13 & LG & TGT & $1.0(3.0 \%)$ & 5.7 \\
& R/8 & LG & AGC & $1.0(2.5 \%)$ & 9.3 \\
NA2 & R/15 & HG & GAT & $1.08(4.0 \%)$ & - \\
& L/20 & HG & GAT & $1.58(4.2 \%)$ & - \\
\hline
\end{tabular}

${ }^{a}$ Site was right $(\mathrm{R})$ or left $(\mathrm{L})$ colon: $\mathrm{R}$ includes caecum, ascending colon, hepatic flexure, transverse colon; L includes splenic flexure, descending colon, sigmoid colon and rectum. Size was indicated by approximate diameter in $\mathrm{mm}$.

${ }^{\mathrm{b}} \mathrm{LG}=$ low grade dysplasia; $\mathrm{HG}=$ high grade dysplasia.

c Wild type codon 12 and 13 were respectively GGT and GGC.

d DNA Index $\neq 1$ was for DNA aneuploidy (DI $=1$ is for DNA diploidy) as detected by flow cytometry. CV stays for Coefficient of Variation of the $\mathrm{G}_{0} / \mathrm{G}_{1}$ DNA diploid/aneuploid peaks. Mean CV obtained from multiple samples of histologically proven normal mucosa from 19 healthy donors was $2.98 \pm 0.39$. In these experimental conditions DNA aneuploid peaks are detected at about $\pm 4 \%$ DNA changes in presence of at least 5-10\% DNA aneuploid cells.

Table 2 shows that the overall incidence of K-ras2 mutations, DNA aneuploidy, and high S-phase values among the 147 adenomas investigated were $6.6 \%$ (9/137), 5.4\% (8/147), and $10.5 \%(15 / 143)$, respectively. S-phase fraction values were considered high when greater than the threshold value of $7.2 \%$. This threshold value was obtained from a series of multiple samples of normal mucosa obtained from 19 healthy donors after addition of 3 Standard Deviations.
DNA aneuploid values (with DNA Index, DI $\neq 1$ ) were near-diploid (DI $\leqslant 1.3$ ) in 5 out of 8 cases. Two patients had 3 synchronous adenocarcinomas. In one patient (PD1), neither of the two adenocarcinomas showed K-ras2, DNA ploidy nor S-phase abnormalities. For the patient NA2, DNA aneuploidy and high S-phase, but no K-ras2 mutation, were detected in the adenocarcinoma investigated. One may observe that Kras2 mutation and DNA aneuploidy incidences among 
Table 4

K-ras2 status, DNA ploidy, S-phase versus site, size, dysplasia, and K-ras2 status versus DNA ploidy and S-phase in 147 adenomas from 4 FAP patients

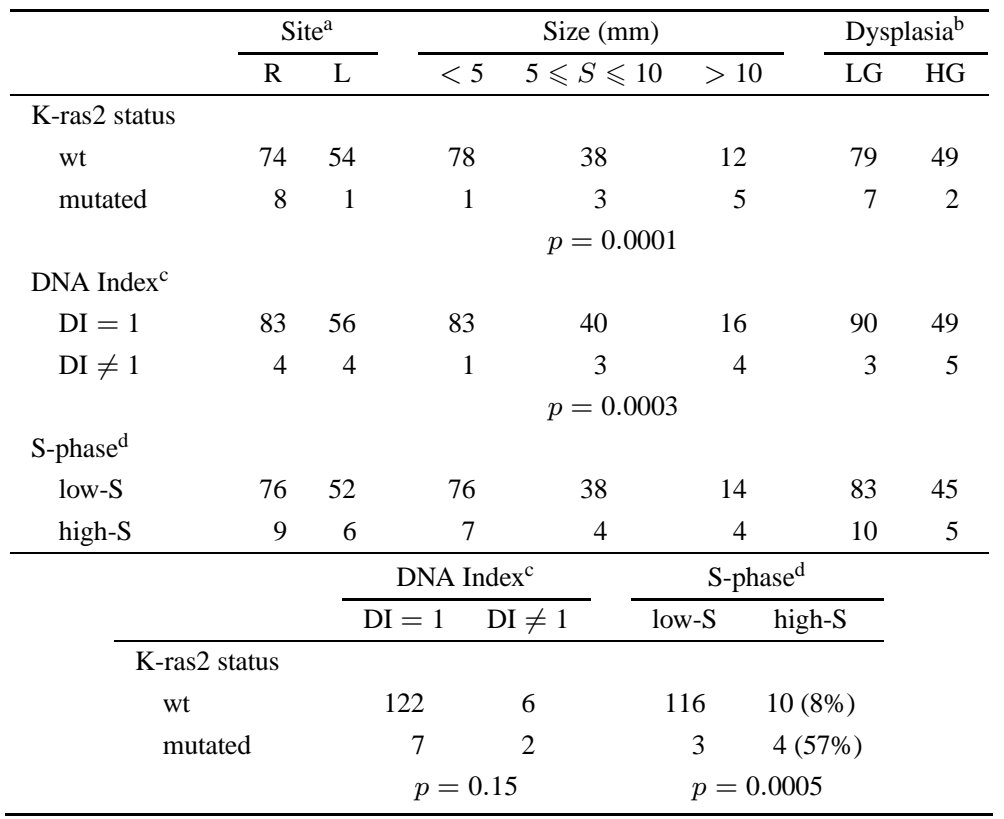

${ }^{a}$ Site was right (R) or left (L) colon: $\mathrm{R}$ includes caecum, ascending colon, hepatic flexure, and transverse colon; $\mathrm{L}$ includes splenic flexure, descending colon, sigmoid colon, and rectum.

${ }^{\mathrm{b}} \mathrm{LG}=$ low grade dysplasia; $\mathrm{HG}=$ high grade dysplasia.

c DNA Index (DI) $\neq 1$ was for DNA aneuploidy (DI $=1$ is for DNA diploidy) as detected by multiparametric flow cutometry.

d High S-phase threshold value was $7.2 \%$ as determined on the basis of the mean Sphase value $(5.1 \pm 0.7 \%)$ added of $3 \mathrm{SD}$ determined in 19 samples of normal mucosa obtained from healthy donors. S-phase was rejected in 4 cases $(2.7 \%)$ due to high CV and background values.

the individual patients ranged widely (from 0 to $67 \%$ ) similarly to high S-phase values (from 0 to $33 \%$ ). Normal FAP mucosa was never found with abnormal values of these three parameters.

The specific K-ras2 mutations, DI and S-phase values of the $9 \mathrm{~K}$-ras 2 mutated adenomas are reported in Table 3 together with site, size, and grade of dysplasia. It is interesting to note the presence of two different K-ras 2 mutations in patients TO1 and PD1. The mutations, $5 \mathrm{G}-\mathrm{T}$ tranversions and $4 \mathrm{G}-\mathrm{A}$ transitions, were mainly detected in low grade dysplastic adenomas $(7 / 9=78 \%)$. Moreover, 8 out of $9 \mathrm{~K}$-ras $2 \mathrm{mu}-$ tated adenomas were located in the right colon. The $\mathrm{S}$ phase fraction exceeded the threshold value of $7.2 \%$ in 4 out of 7 mutated adenomas. It should be noted that only 2 among the 9 K-ras 2 mutated adenomas were DNA aneuploid.

Table 4 shows K-ras2 status, DNA ploidy and Sphase fraction versus site, size and dysplasia, and $\mathrm{K}$ - ras2 status versus DNA Index and S-phase fraction. It is to be noted that there is a progressive increase of the number of K-ras2 mutated adenomas, as well as of the DNA aneuploid adenomas, with increase of size ( $p=0.0001$ and $p=0.003$, respectively). K-ras2 was not correlated with DNA Index but showed a statistically significant correlation with S-phase fraction, i.e., mutated adenomas had high S-phase in $57 \%$ of the cases versus $8 \%$ for the wild type $(p=0.0005)$.

\section{Discussion}

Human colorectal adenomas arising in Familial Adenomatous Polyposis (FAP) syndrome patients are associated to the germ line mutation of the APC oncosuppressor gene $[17,22,24,33]$ and to a somatic alteration of the second normal allele [20,28,29,31] according to the two-hits hypothesis of Knudson [26]. While 
the initiating events of the human FAP syndrome are well established, later genotypic events associated with tumour progression are not yet well known. We have presently studied the role of K-ras2 activation and aneuploidy in relationship with a possible proliferative gain and increased growth in size using in vast majority small adenomas ( $86 \%$ were smaller than $10 \mathrm{~mm}$ ). Analyses were performed on fresh-frozen material by taking multiple specimens from every lesion. One patient was studied in greater details by mapping and investigating 123 adenomas. Flow cytometry was used to measure relative DNA content to provide the degree of DNA aneuploidy (also known as DNA Index, DI) and the S-phase fraction. The same samples were also investigated by sequence specific oligonucleotide hybridization in codon 12 and 13 to provide the K-ras2 mutation spectrum.

Normal FAP mucosa and mucosa from healthy donors were investigated for comparison and were never found to give abnormal values of K-ras2 status, DNA ploidy and S-phase fraction.

K-ras2 mutation incidence among the present series of 147 adenomas was about $7 \%$. K-ras 2 mutations and size were strongly correlated: among small adenomas (size $<5 \mathrm{~mm})$ only about $1 \%(1 / 79)$ were mutated versus $30 \%$ of the large ones (size $>10 \mathrm{~mm}$ ). Moreover, $57 \%$ among the K-ras2 mutated adenomas (versus $8 \%$ of wild type K-ras 2 ) showed S-phase fraction greater than the threshold value of $7.2 \%(p=0.0005)$.

Thus, the present study provides experimental evidence that neither K-ras2 activation nor DNA aneuploidy are a characteristic of small adenomas among FAP syndrome patients. Previous studies had already shown that K-ras 2 oncogene activation appears associated to a more aggressive phenotype in larger FAP adenomas [2,9,20,27,42]. The positive relationship of K-ras2 activation and a proliferative gain in FAP patients, however, was not previously reported using the present techniques. This finding is different for human sporadic colorectal adenomas where K-ras 2 mutations (and, in particular, $\mathrm{G} \rightarrow \mathrm{A}$ transitions) were associated to inhibition of proliferation [12]. It is likely that this difference arises from the fact that FAP adenomas are in presence of alteration of both the APC alleles. In addition, the fact that K-ras2 mutations were already detected up to about $85 \%$ in human colorectal aberrant crypt foci in sporadic cancer patients [35,36,38,41,44], suggests that K-ras2 activated lesions without APC inactivation have little potential to progress.

Interestingly and newly in comparison with previous studies, we have also detected a statistically significant correlation between DNA aneuploidy and size ( $p=$ 0.003 ). DNA aneuploidy incidence was, in fact, only about $1 \%$ in the small adenoma class (size $<5 \mathrm{~mm}$ ) and $20 \%$ for the large adenomas (size $>10 \mathrm{~mm}$ ).

Thus, loss of chromosome stability appears to be an acquired mechanism toward an increase in size and potentially malignant characteristics. DNA aneuploidy was reported to be absent in aberrant crypt foci in both FAP and sporadic patients [30] and to be above $20 \%$ among human sporadic colorectal adenomas with different sizes with mild-moderate dysplasia and up to $50 \%$ and $70 \%$ in respectively severe dysplastic adenomas and adenomas with early cancer [14]. The data in literature regarding aneuploidy in FAP tumours are quite few. DNA aneuploid subclones detected in the present series of FAP adenomas were near-diploid $(\mathrm{DI} \leqslant 1.3$ ) in about $63 \%$ of the cases. This finding is in agreement with our previous data in human sporadic adenomas in which aneuploid subclones were in the near-diploid range in about $70 \%$ of the cases $[11,14]$.

Chromosome instability and aneuploidy appear to be dependent on very complex molecular mechanisms that still remain unknown. A possible link of aneuploidy with mutations of K-ras2 oncogene and p53 in human sporadic preneoplastic colorectal lesions has been recently reviewed [13]. Several experimental studies performed both in vitro, using mainly K-ras2 mutated transfected cell lines [18,32], and in vivo, using human colorectal sporadic adenomas of increasing size $[12,15]$, suggest a possible role of K-ras2 gene mutations in affecting chromosome stability. In the present study, however, among $9 \mathrm{~K}$-ras 2 mutated FAP adenomas, only 2 were DNA aneuploid. The present findings suggest that K-ras2 activation in FAP adenomas cooperates mainly to alter the proliferative status without affecting the genome stability.

A possible role of K-ras2 activation to inhibit apoptosis, as previously suggested using in vitro colon cell lines [3] and human sporadic preneoplastic and neoplastic colorectal lesions $[5,43]$, may be postulated also for adenomas among patients with the FAP syndrome but remains to be proven.

In any case, since the majority of the small adenomas are obtained from one patient, it is not possible to rule out that individual variations could have yielded these results in terms of K-ras 2 mutation and aneuploidy incidences. Thus, a larger cohort of FAP patients are required to confirm our hypotheses.

In conclusion, the present data suggest that K-ras2 mutations and DNA aneuploidy are correlated to an increased cell proliferation and tumour size in a sub- 
group of FAP adenomas, suggesting the possibility that these biomarkers may be used in predicting tumour progression and response to agents potentially useful to induce adenoma regression.

\section{Acknowledgements}

This study was financially supported by the Italian Health Ministry, by the Novello Foundation held in Turin for therapy improvement of human colorectal neoplasia, and by the Italian Association for Cancer Research (A.I.R.C.) for hereditary colorectal cancer.

\section{References}

[1] H. Aktas, H. Cai and G.M. Cooper, Ras links growth factor signaling to cell cycle machinery via regulation of cyclin D1 and the CdK inhibitor p27 KIP1, Mol. Cell Biol. 17 (1997), 3850-3857.

[2] M. Ando, K. Takemura, M. Maruyama, M. Endo, T. Iwama and Y. Iuasa, Mutations in c-Kras 2 gene codon 12 during colorectal tumorigenesis in Familial Adenomatous Polyposis, Gastroenterology 103 (1992), 1725-1731.

[3] N. Arber, E. Kyu-Ho Han., A. Sgambato, G.A. Piazza, T.M. Delohery, M. Begemann, C.M. Weghorst, N.H. Kim, R. Pamukcu, D.J. Ahnen, J.C. Reed, I.B. Weinstein and P.R. Holt, A K-ras oncogene increases resistance to sulindacinduced apoptosis in rat enterocytes, Gastroenterology 113 (1997), 1892-1900.

[4] N. Arber, H. Hibshoosh, S.F. Moss, S.F. Sutterx, Y. Zhang, M. Begg, S. Wang, B. Weinstein and P.R. Holt, Increased expression of cyclin D1 is an early event in multistage colorectal carcinogenesis, Gastroenterology 110 (1996), 669-674.

[5] A. Bedi, P.J. Pasricha, A.J. Akhtar, J.P. Barber, G.C. Bedi, F.M. Giardiello, B.A. Zehnbauer, S.R. Hamilton and R.J. Jones, Inhibition of apoptosis during development of colorectal cancer, Cancer Res. 55 (1995), 1811-1816.

[6] G. Bollag and F. McCormick, Regulators and effectors of ras proteins, Ann. Rev. Cell Biol. 7 (1991), 601-632.

[7] J.L. Bos, E.L. Fearon, S.R. Hamilton, M. Verlaan de Vries, J.H. van Boom, A.J. Van der Eb and B. Vogelstein, Prevalence of ras gene mutations in human colorectal cancers, Nature 327 (1987), 293-297.

[8] C.Y. Chen and D.V. Faller, Direction of p21ras-genereated signals towards cell growth or apoptosis is determined by protein kinase C and Bcl-2, Oncogene 11 (1995), 1487-1498.

[9] E.R. Fearon and B. Vogelstein, A genetic model for colorectal tumorigenesis, Cell 61 (1990), 759-767.

[10] J.L. Fleiss, Statistical Methods for Rates and Proportions, 2nd edn., John Wiley and Sons, New York, 1981.

[11] W. Giaretti, A model of DNA aneuploidization and evolution in colorectal cancer, Lab. Invest. 71 (1994), 904-910.
[12] W. Giaretti, A. Rapallo, E. Geido, A. Sciutto, F. Merlo, M. Risio and F.P. Rossini, Specific K-ras2 mutations in human sporadic colorectal adenomas are associated to DNA near-diploid aneuploidy and inhibition of proliferation, Am. J. Path. 153 (1998), 1201-1209.

[13] W. Giaretti, Aneuploidy mechanisms in human colorectal preneoplastic lesions and Barrett's esophagus. Is there a role for K-ras and p53 mutations?, Anal. Cell Path. 15 (1997), 99-117.

[14] W. Giaretti and L. Santi, Tumour progression by DNA flow cytometry in human colorectal cancer, Int. J. Cancer 45 (1990), 597-603.

[15] W. Giaretti, N. Pujic, A. Rapallo, S. Nigro, A. Di Vinci, E. Geido and M. Risio, K-ras2 G-C and G-T transversions correlate with DNA aneuploidy in colorectal adenomas, Gastroenterology 108 (1995), 1040-1047.

[16] W. Giaretti, S. Sciallero, S. Bruno, E. Geido, H. Aste and A. Di Vinci, DNA flow cytometry of endoscopically examined colorectal adenomas and adenocarcinomas, Cytometry 9 (1988), 238-244.

[17] J. Groden, A. Thliveris, W. Samowitz, M. Carlson, L. Gelbert, H. Albertsen, G. Joslyn, J. Stevens, L. Spirio, M. Robertson, L. Sargeant, K. Krapcho, E. Wolff, Burt R., J.P. Hughes, J. Warrington, J. McPherson, J. Wasmuth, D. Le Paslier, H. Abderrahim, D. Cohen, M. Leppert and R. White, Identification and characterization of the familial adenomatous polyposis coli gene, Cell 66 (1991), 589-600.

[18] N. Hagag, L. Diamond, R. Palermo and S. Lyubsky, High expression of ras p21 correlates with increased rate of abnormal mitosis in NIH3T3 cells, Oncogene 5 (1990), 1481-1489.

[19] A. Hall, Small GTP-binding proteins and the regulation of the actin cytoskeleton, Annu. Rev. Cell Biol. 10 (1994), 31-54.

[20] S. Ichii, S. Takeda, A. Horii, S. Nakatsuru, Y. Miyoshi, M. Emi, Y. Fujiwara, K. Koyama, J. Furuyama, J. Utsunomiya and Y. Nakamura, Detailed analysis of genetic alterations in colorectal tumors from patients with and without familial adenomatous polyposis (FAP), Oncogene 8 (1993), 2399-2405.

[21] J.R. Jass and L.H. Sobin, Histological typing of intestinal tumors, in: WHO International Histological Classification of Tumors, Springer-Verlag, Berlin, 1989.

[22] G. Joslyn, M. Carlson, A. Thliveris, H. Albertsen, L. Gelbert, W. Samowitz, J. Groden, J. Stevens, L. Spirio, M. Robertson, L. Sargeant, K. Krapcho, E. Wolff, R. Burt, J.P. Hughes, J. Warrington, J. McPherson, J. Wasmuth, D. Le Paslier, H. Abderrahim, D. Cohen, M. Leppert and R. White, Identification of deletion mutations and three new genes at the familial polyposis locus, Cell 66 (1991), 601-613.

[23] R. Khosravi-Far, S. Campbell, K.L. Rossman and C.J. Der, Increasing complexity of Ras signal transduction: involvement of Rho family proteins, Adv. Cancer Res. 72 (1998), 57-107.

[24] K.W. Kinzler, M.C. Nilbert, L. Su, B. Vogelstein, T.M. Bryan D.B. Levy, K.J. Smith, A.C. Preisinger, P. Hedge, D. McKechnie, R. Finniear, A. Markham, J. Groffen, M.S. Boguski, S.F. Altschul, A. Horii, H. Ando, Y. Miyoshi, Y. Miki, I. Nishisho and Y. Nakamura, Identification of FAP locus genes from chromosome 5q21, Science 253 (1991), 661-665.

[25] W.K. Kinzler and B. Vogelstein, Lessons from hereditary colorectal cancer, Cell 87 (1996), 159-170.

[26] A.G. Knudson, Hereditary cancer, oncogenes, and antioncogenes, Cancer Res. 45 (1985), 1437-1443. 
[27] M. Miyaki, M. Seki, M. Okamoto, A. Yamanaka, Y. Maeda, K. Tanaka, R. Kikuchi, T. Iwama, T. Ikeuchi, A. Tonomura, Y. Nakamura, R. White, Y. Miki, J. Utsunomiya and M. Koike, Genetic changes and histopathological types in colorectal tumors from patients with familial adenomatous polyposis, Cancer Res. 50 (1990), 7166-7173.

[28] Y. Miyoshi, H. Ando, H. Nagase, I. Nishisho, A. Horii, Y. Miki, T. Mori, J. Utsunomiya, S. Baba, G. Petersen, S.R. Hamilton, K.W. Kinzler, B. Vogelstein and Y. Nakamura, Germ-line mutations of the APC gene in 53 familial adenomatous polyposis patients, Proc. Natl. Acad. Sci., USA 89 (1992), 4452-4456.

[29] H. Nagase, Y. Miyoshi, A. Horii, T. Oki, M. Ogawa, J. Utsunomiya, S. Baba, T. Sasazuki and Y. Nakamura, Correlation between the location of germ-line mutations in the APC gene and the number of colorectal polyps in familial adenomatous polyposis patients, Cancer Res. 52 (1992), 4055-4057.

[30] S. Nakamura, I. Kino and S. Baba, Nuclear DNA content of isolated crypts of background colonic mucosa from patients with familial adenomatous polyposis and sporadic colorectal cancer, Gut 34 (1993), 1240-1244.

[31] Y. Nakamura, The role of the Adenomatous Polyposis Coli (APC) gene in human cancers, Adv. Cancer Res. 62 (1993), 65-87.

[32] S. Nigro, E. Geido, E. Infusini, R. Orecchia and W. Giaretti, Transfection of human mutated K-ras in mouse NIH-3T3 cells is associated with increased cloning efficiency and DNA aneuploidization, Int. J. Cancer 67 (1996), 871-875.

[33] I. Nishisho, Y. Nakamura, Y. Miyoshi, Y. Miki, H. Ando, A. Horii, K. Koyama, J. Utsunomiya, S. Baba, P. Hedge, A. Markham, A.J. Krush, G. Petersen, S.R. Hamilton, M.C. Nilbert, D.B. Levy, T.M. Bryan, A.C. Preisinger, K.J. Smith, L. Su, K.W. Kinzler and B. Vogelstein, Mutations of chromosome 5q21 genes in FAP and colorectal cancer patients, Science 253 (1991), 665-669.

[34] C.D. Nobes and A. Hall, Rho, rac, and cdc42 GTPases regulate the assembly of multimolecular focal complexes associated with actin stress fibers, lamellipodia, and filopodia, Cell 81 (1995), 53-62.
[35] K. Otori, K. Sugijama, T. Hasebe, S. Fukushima and H. Esumi, Emergence of adenomatous aberrant crypt foci (ACF) from hyperplastic ACF with concomitant increase in cell proliferation, Cancer Res. 55 (1995), 4743-4746.

[36] P.T. Pretlow, Aberrant crypt foci and K-ras mutations: early recognized players or innocent bystenders in colorectal carcinogenesis?, Gastroenterology 108 (1995), 600-603.

[37] T. Ried, R. Knutzen, R. Steinbeck, H. Blegen, E. Schrock, K. Heselmeyer, S. du Manoir and G. Auer, Comparative genomic hybridization reveals a specific pattern of chromosomal gains and losses during the genesis of colorectal tumors, Genes Chromosome Cancer 15 (1996), 1-5.

[38] L. Roncucci, A. Medline and W.R. Bruce, Classification of aberrant crypt foci and microadenomas in human colon, Cancer Epidemiol. Biomarkers Prev. 1 (1991), 57-60.

[39] J. Sambrook, E.F. Fritsch and T. Maniatis, Molecular Cloning, Cold Spring Harbour Laboratory Press, New York, 1989.

[40] M. Serrano, E. Gomez-Lahoz, R.A. DePinho, D. Beach, and D. Bar-Sagi, Inhibition of Ras-induced proliferation and cellular transformation by $\mathrm{p} 16^{\mathrm{INK} 4}$, Science 267 (1995), 249-252.

[41] T. Takayama, S. Katsuki, Y. Takahashi, M. Ohi, S. Nojiri, S. Sakamaki, J. Kato, K. Kogawa, H. Miyake and Y. Niitsu, Aberrant crypt foci of the colon as precursors of adenoma and cancer, New Engl. J. Med. 339 (1998), 1277-1284.

[42] B. Vogelstein, E.R. Fearon, S.R. Hamilton, S. Kern, A.C. Preisinger, B.A.M. Leppert, Y. Nakamura, R. White, A.M.M. Smits and J.L. Bos, Genetic alterations during colorectaltumour development, New Engl. J. Med. 319 (1988), 525-532.

[43] R.L. Ward, A.V. Todd, F. Santiago, T. O'Connor and N. Hawkins, Activation of the K-ras oncogene in colorectal neoplasms is associated with decreased apoptosis, Cancer 79 (1997), 1106-1113.

[44] N. Yamashita, T. Minamoto, A. Ochiai, M. Onda and H. Esumi, Frequent and charateristic K-ras activation and absence of p53 protein accumulation in aberrant cript foci of the colon, Gastroenterology 108 (1995), 434-440. 


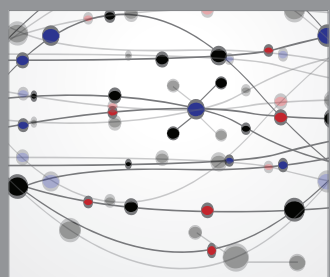

The Scientific World Journal
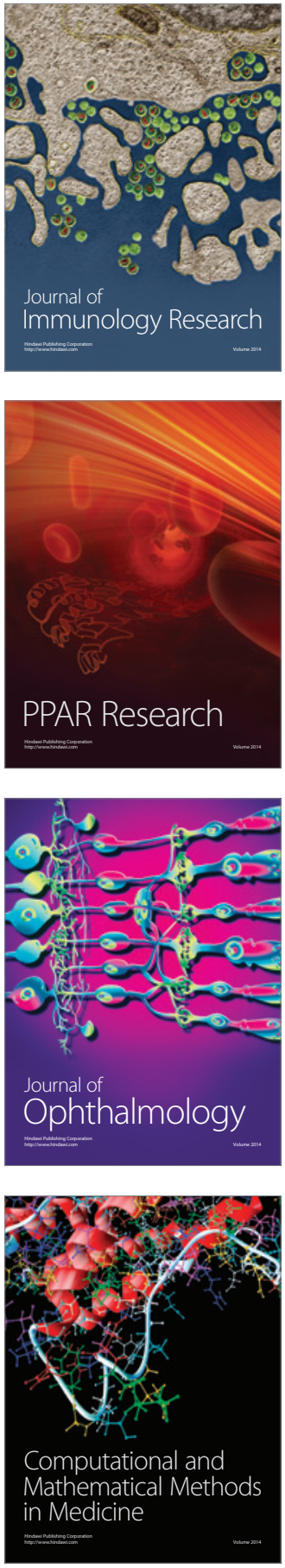

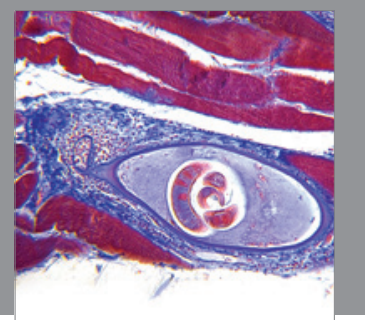

Gastroenterology

Research and Practice
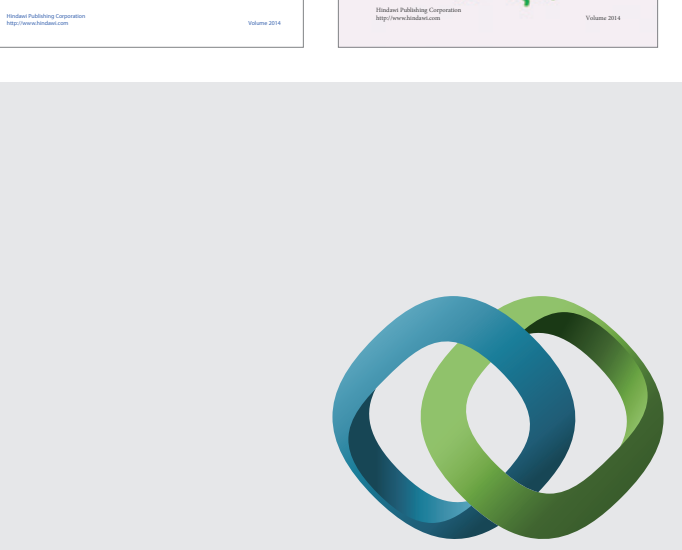

\section{Hindawi}

Submit your manuscripts at

http://www.hindawi.com
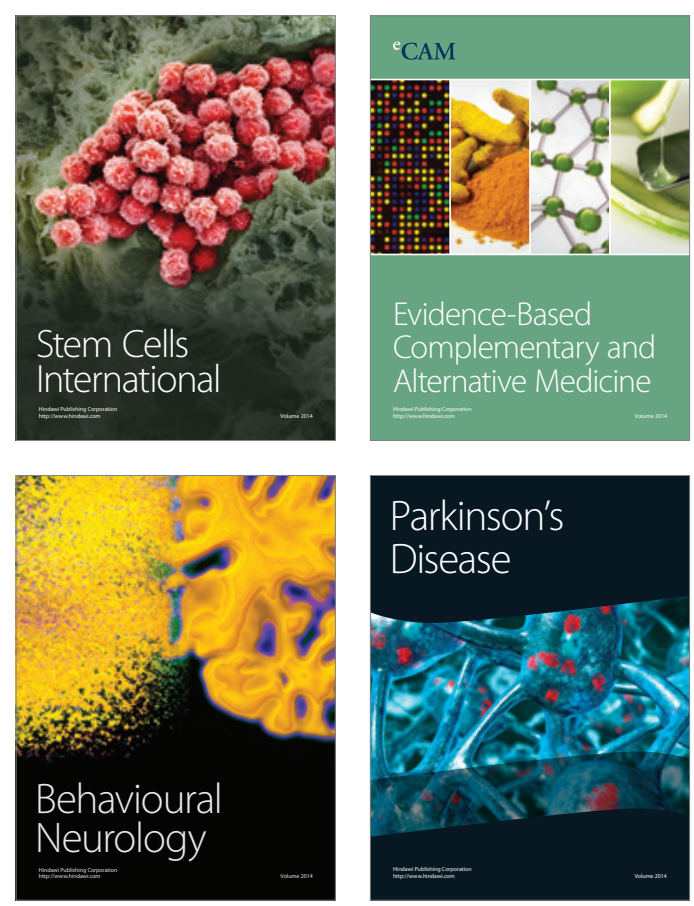

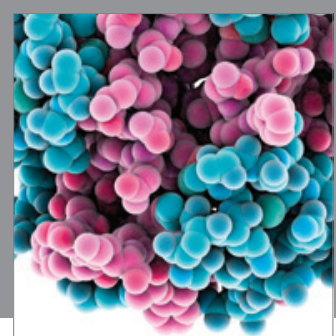

Journal of
Diabetes Research

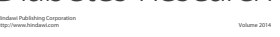

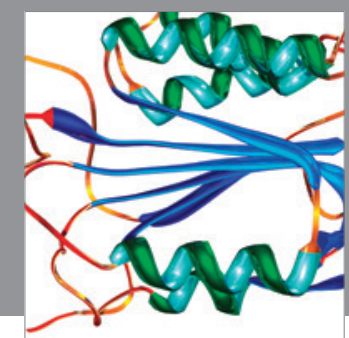

Disease Markers
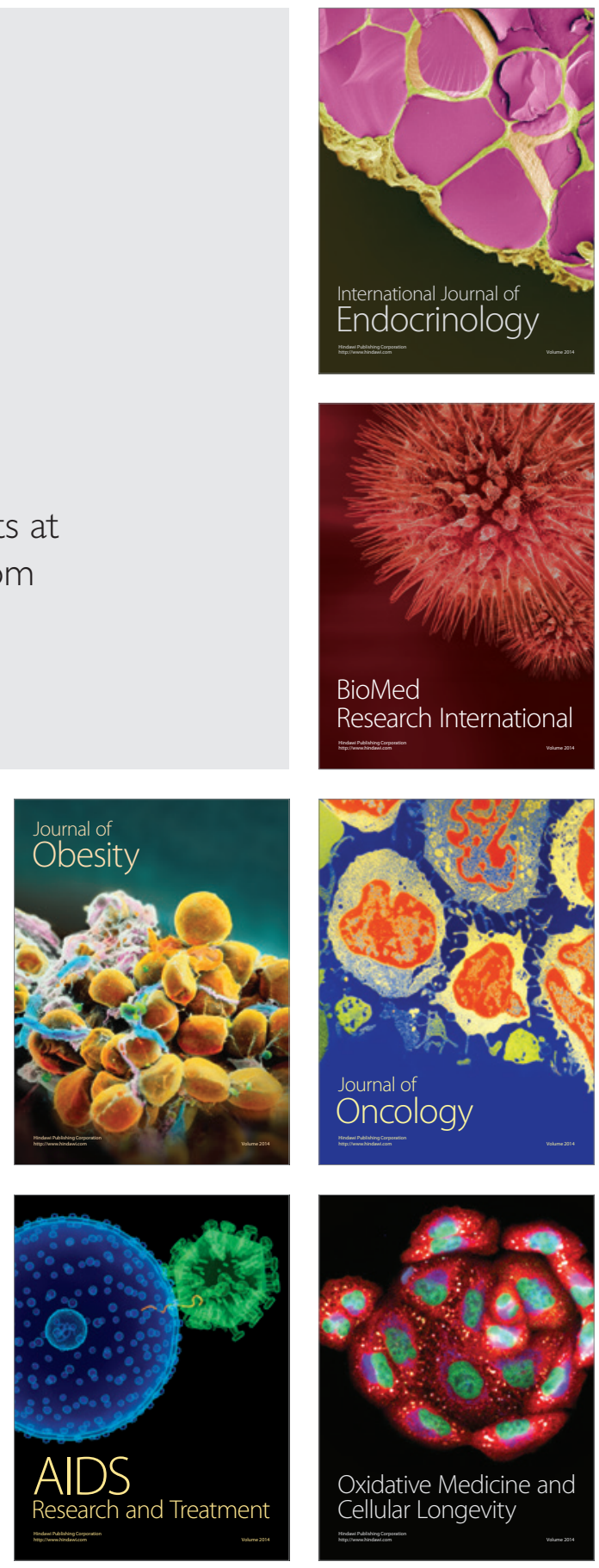